\title{
Religião e ensino religioso na escola
}

\author{
Religion and religious teaching at school
}

Arnaldo Érico Huff Júnior

RESUMO

\begin{abstract}
O texto pretende tratar de alguns dos problemas centrais que envolvem a presença da religião e do Ensino Religioso na escola. As questões principais dizem respeito ao objeto do ensino religioso e à natureza de sua epistemologia. $\bigcirc$ Ensino Religioso deve ser o ensino de religião? Pressupostos religiosos, como a crença em Deus, estão implicados no Ensino Religioso? O Ensino Religioso na escola é, afinal, religioso ou acadêmico? Qual sua relação com as demais disciplinas das Humanidades? E com a Ciência da Religião? Qual o conceito de religião implicado no Ensino Religioso? Estas são as perguntas centrais discutidas no artigo. A opinião sustentada é de que o objeto do Ensino Religioso é a religião enquanto fenômeno humano e que a epistemologia da disciplina pertence ao campo das Humanidades, especificamente à Ciência da Religião.
\end{abstract}

Palavras-chave: Ensino Religioso, Religião, Escola, Ciência da Religião Aplicada

\section{ABSTRACT}

This paper intends to approach some of the central problems related to the presence of religion and Religious Teaching at school. The main topics are the object of Religious Teaching and the nature of its epistemology. Religious Teaching must be the teaching of religion? Religious assumptions, like the belief in God, are implied in Religious Teaching? Is Religious Teaching at school, in the end, religious or academic? What is its relation with other disciplines of the Humanities? And with the Science of Religion? What is the concept of religion involved in Religious Teaching? These are the central questions discussed in the article. The position sustained is that the object of Religious Teaching is religion as a human phenomenon and that the epistemology of the discipline belongs to the field of the Humanities, mostly to the Science of Religion.

\section{Keywords: Religious Teaching, Religion, School, Applied Religious Studies}

1 Doutor em Ciência da Religião e História Social, Professor do Departamento de Ciência da Religião da UFJF. Email: huffjr_@hotmail.com .Submetido em: 05/10/2020. Aprovado em: 30/12/2020. 


\section{Introdução}

A questão da religião na escola, assim como na universidade, continua sendo um problema, que se apresenta, principalmente, de duas formas: trata-se de algo que encontra resistência (a) em função da tradição cientificista; (b) e/ ou em meio a uma situação de pluralidade cultural experimentada de modo conflitivo. Enfrentar tal problema e lidar com essa dupla questão é tarefa urgente dos profissionais do Ensino Religioso, bem como da escola como um todo, especialmente das equipes diretivas. Os horizontes aqui entrevistos consistem em compreender o Ensino Religioso (ER) como ensino de religião no âmbito da Ciência da Religião Aplicada, pertencente ao contexto amplo das Humanidades (entendidas, aqui, com o conjunto de disciplinas que compõem as ciências humanas, as letras e as artes).

\section{Questões que se colocam no horizonte do Ensino Religioso escolar}

\section{$1.1 \bigcirc$ que se ensina no Ensino Religioso? Religião ou valores?}

Logo quando iniciou-se o processo de criação da graduação em Ciência da Religião em minha universidade, eu e um colega professor convidamos pessoas envolvidas diretamente com - ER em escolas estaduais do município para nos ajudar, dialogando conosco sobre suas experiências. A ideia era simples: que tivéssemos um fundamento prático para a criação do curso, algo que evitasse a distância que muitas vezes existe entre a universidade e a escola, ou mesmo entre a universidade e a vida vivida cotidianamente. Queríamos ouvir os professores e as questões que eles nos tinham para acrescentar. Logo no princípio, fomos interpelados pela seguinte indagação, vinda, como se diz, do "chão da escola": o ER deve ser ensino de religião? Dar aulas de religião, afinal, traz muitos conflitos. A questão, de fato, se coloca diante de impasses diversos e normalmente a resposta pende a constituir uma saída para evitar tais conflitos.

O primeiro dos problemas diz respeito à própria comunidade escolar. Um ensino religioso que pretenda abarcar outras religiões que não apenas o cristianismo tende a gerar conflitos entre a escola e as famílias dos alunos. Todos teríamos inúmeras histórias para contar. O que acontece é que a religião cria um mundo de sentido, um universo habitável para se viver, um horizonte para a vida (ALVES, 1981, p. 14ss). Quando, todavia, conhecemos unicamente ou de modo mais profundo apenas o nosso mundo de sentido, outros universos desconhecidos parecem assombrosos. As reações podem ir do medo ao ódio. É como se algo diferente ameaçasse nossa própria constituição pessoal. Por isso as famílias reagem às vezes violentamente no tocante às questões do ER.

Agregue-se, nesse sentido, o grande conservadorismo que tem aflorado no Brasil e no mundo. Em nosso país, o tipo mais barulhento de conservadorismo é o evangélico. Os casos de intolerância religiosa por parte de evangélicos são inúmeros. Os mais vistosos dizem respeito às religiões de matriz africana. $O$ processo aqui é de nítida demonização do outro. À medida que o universo do outro me desafia, como um espelho, ao invés de encará-lo como alteridade, desconsidero-o como um universo de sentido válido, e o construo como o mal, o não-ser, o caos, o demônico. Este normalmente é o resultado do fundamentalismo religioso. ${ }^{2}$ Acontece, porém, que não se trata de um problema apenas dos evangélicos. Se fosse seria dos males o menor. Os evangélicos são tão somente os mais barulhentos, visto que estão na grande mídia e se manifestam de modo organizado e contundente no espaço público. Não obstante, a intolerância e a perseguição constituem uma realidade endêmica à história brasileira. As religiões dos povos originários, as de matriz africana e o judaísmo foram demonizadas pelos europeus católicos no período colonial. Protestantes foram demonizados por católicos no período pós- 
independência. Umbandistas sofreram forte resistência de espíritas kardecistas. Protestantes históricos, de um modo geral, apartam-se de todos numa cruzada salvacionista, demonizando especialmente as religiões afro, mas também o kardecismo e o catolicismo. Por sua vez, o catolicismo atual, ainda o fenômeno religioso hegemônico no Brasil, possui diversas faces conservadoras e apequenantes das diferenças; desde organizações de inspiração medieval como os Arautos do Evangelho, até a Renovação Carismática Católica, passando por toda a hierarquia estabelecida religiosa e politicamente, acostumada por séculos a seus mandos e desmandos. Tais lutas de poder inerentes ao universo das religiões no Brasil já foram amplamente analisadas em estudos feitos principalmente no campo das Ciências Sociais e da História. ${ }^{3}$ É preciso, todavia, falar ainda da demonização da religião que surge por parte da própria universidade, seja ela de matriz positivista, marxista ou mesmo humanista - coisa que ainda se vê por aí. Religião, nesse horizonte academicamente estreito, é coisa alienante ou ilusória, de gente pobre, deseducada e insana. Pois bem, é justamente este o cenário no qual atuamos como educares interessados em religião. É com tal horizonte que temos que lidar, nosso "feijão com arroz" mais cotidiano.

Tudo isso traz à tona dois temas correlatos que surgem como reações aos conflitos mencionados: por um lado, a prática do ER como catequese e, por outro, do ER como ensino de valores. Em relação à catequese, trata-se de algo centenário em nosso meio. $O$ ER foi de fato, até a constituição de 1988, principalmente catequético-proselitista. E ainda o é em diversos sentidos e em inúmeros lugares - o que é um problema real, ainda mais no caso da escola pública, que deveria acolher as várias manifestações religiosas e culturais. De qualquer forma, a catequese na escola ainda faz muito sentido em muitos lugares, uma vez que não desaloja ou desinstala os comportamentos estabelecidos. Deixa a ordem e o status quo como estão, evitandose assim o conflito. É como encontrar um gigante (a catequese católica, por exemplo), do qual é preciso apenas desviar se não se quer brigar com ele. A menos que se o importune dizendo que ele pode ser grande mas não é o único, ele não vai atacar. Como consequência, tudo permanece como sempre esteve. Nesse sentido, de alguma forma, a catequese pode ajudar apaziguar as relações e evitar o confronto.

Há, também, por outro lado, o horror à catequese, que pode desembocar em uma proposta pedagógica que anula no ER sua própria essência, qual seja, o saber sobre as religiões. Como isso se dá? Constitui uma outra forma de evitar o conflito. Uma vez que o ensino da religião causa problemas na comunidade escolar; que pais e familiares se indispõem com professoras, coordenadoras e diretoras cada vez que veem suas crianças e adolescentes interpelados por um universo religioso diferente, seja por medo ou por ódio; a proposta pedagógica para o ER migra para a abordagem de valores, um terreno neutro, no qual se pode navegar tranquilamente. A estratégia consiste em extrair das religiões, principalmente do cristianismo, a interpretação de determinados pressupostos éticos. Os temas podem inclusive ser polêmicos como o aborto, por exemplo, mas as respostas serão invariavelmente moralistas, no sentido de prontas, prescritivas, que tendem mais a ensinar, no sentido bancário, que a fazer pensar.

Ora, a estratégia de entrada no ER pela via dos valores é, por um lado, redutora do fenômeno religioso; e por outro, atribui ao professor de ER uma tarefa que é dever de toda a comunidade escolar. Ainda que as religiões detenham um forte componente ético, não é possível reduzi-las apenas à sua dimensão ética. Ninian Smart (1995), por exemplo, elenca diversas outras dimensões da religião, além da ética: a mítica, a ritual, a doutrinal, a social, a experiencial, a política, a material. A religião não é um fenômeno unidimensional. Reduzi-la à ética é extirparIhe a natureza e a força, é cortar pela raiz outras possibilidades de sentido. A dimensão ética da religião é importantíssima, mas não é a única. Reduzir a religião à ética é abrir a guarda para a entrada de um moralismo nocivo à educação. Quando se faz isso, a caricatura que me vem à

3 P. ex.: Vainfas e Souza (2000); Giumbelli (2003); Silva (2007). 
mente é a da professora de religião chamada pela direção para lidar com aquela turma de $5^{\circ}$ ano cheia de "pestinhas" que "não sabem se comportar", a quem se diz: "vá lá e dê um jeito neles", "acalma essa criançada pra gente poder trabalhar"... Ou seja, não se abre janelas para o entendimento inteligente e criativo do mundo, que é o que a educação deveria fazer, mas apenas domestica-se os alunos a um padrão de moralidade estabelecido, informado por valores cristãos culturalmente hegemônicos - e isso sem perceber que mesmo dentro do cristianismo pode haver outras formas de entendimento ético.

Ainda por outro lado, a formação ética dos alunos não pode, obviamente, ser entendida como uma tarefa exclusiva da professora de ER. Trata-se de um desafio permanente de toda a comunidade escolar, incluindo aqui as famílias dos alunos. Da formação ética são responsáveis diretamente todas as disciplinas, cada uma com acentos ou nuances diferentes. Professores de história, de filosofia, de artes, mas também de português, matemática e ciências podem e devem ter no horizonte um processo pedagógico que privilegie a inserção responsável e amorosa no mundo, uma compreensão da vida como relação e pertença ao próximo e à natureza, uma compreensão holística e ecológica. Isso tem a ver, é claro, com religião, e pode ser inclusive um lugar privilegiado do $E R$, mas nele não se esgota.

A questão do apaziguamento irenista dos conflitos e a redução do ER ao ensino de valores são problemas fulcrais que temos de lidar hoje, além, é claro, do velho problema da catequese em sala de aula.

\subsection{Se o ER ensina religião, ele é religioso ou acadêmico?}

Toda essa problemática coloca, é claro, em questão a pertinência do ER no projeto de educação nacional. Uma das reclamações reiteradas entre professores de ER é a falta de entendimento de colegas e diretores em relação à religião e ao específico do ER. A situação tem claras implicações em relação ao "que fazer" do ER diante de problemas centrais como os acima elencados. Se não se entende adequadamente o ER como parte de um projeto educacional amplo, fica impossível lidar adequadamente com as questões societárias que vivenciamos no tocante à religião e ao ensino sobre ela na escola local.

Nesse sentido, a legislação e as práticas jurídicas que temos são desconcertantes e não colaboram muito. A Constituição Federal afirma que o ER deve ser ofertado no horário normal e que sua matrícula deve ser facultativa; ao passo que se sabe que em diversos sistemas de ensino, como no município de Juiz de Fora, por exemplo, a disciplina simplesmente não é oferecida e, quando o é, a matrícula facultativa não funciona exatamente bem. A Lei de Diretrizes e Bases da Educação Nacional (LDB), por sua vez, delega aos sistemas de ensino (municipais e estaduais) a regulação dos conteúdos e a formação dos professores; ao passo que a $4^{\mathrm{a}}$ versão da Base Nacional Comum Curricular (BNCC) estabelece conteúdos e diretrizes para o ER em nível nacional e que a Resolução $n^{\circ} 5$ de 28 de dezembro de 2018 do Conselho Nacional de Educação (CNE) estabelece diretrizes curriculares nacionais para os cursos de Licenciatura em Ciências da Religião. A LDB indica, ainda, que estão vedadas quaisquer formas de proselitismo no ER; ao passo que o STF em 2017 atestou a constitucionalidade do ER de molde confessional, o que ratifica a legitimidade do acordo Brasil-Santa Sé, feito em 2008, que ganhou forma de lei no decreto $7107 / 10$. Tudo indica uma situação politicamente conflituosa e ainda inacabada. ${ }^{4}$

4 Note-se, todavia, que é possível pensar o ER catequético-proselitista como algo diferente do modelo de ER confessional, ao qual vai quem já se identifica com determinada confissão e no qual há invariavelmente uma possibilidade mínima de escolha - como no caso do RJ, ao menos teoricamente. Já no modelo catequéticoproselitista impõe-se como religião verdadeira aos alunos apenas uma confissão religiosa, sem possibilidade de escolha. De qualquer modo a fronteira entre ambos é porosa e nossa perspectiva é a da inadequação de ambos os modelos. 
A versão da BNCC em vigor, depois de idas vindas, alocou o ER como área independente em relação às áreas de Linguagens (língua portuguesa, artes, educação física e língua inglesa) e de Ciências Humanas (geografia e história); o que não é ainda exatamente ideal para encontrar saídas consistentes. De qualquer forma, a presença do ER na Base, mesmo que em desacordo com a LDB, já é por si só uma vitória política, considerando as disputas históricas em questão.

Tenho comigo, todavia, que a alocação do ER fora das Humanidades favorece uma certa ideia de que ele possui no fundo uma epistemologia religiosa, e não acadêmica. A base dessa compreensão é o entendimento de religião como algo que envolve uma relação com ser(es) espirituais, sobrenaturais. Assim, religião seria a crença de que determinados entes espirituais, imateriais, afetam a vida humana, e demandam, por isso, uma relação pessoal. Se o ER é, portanto, ensino de religião (entendendo-o nesse sentido em uma forma catequética) ele pressupõe a existência de tais seres espirituais. A epistemologia do ER seria, desse modo, dependente da existência de tais entes sobrenaturais, aproximando-se, nessa ótica, da teologia eclesiástica. Ora, é razoável argumentar que a existência de tais seres espirituais não é passível de comprovação objetiva, científica, dependendo de que se acredite que eles existam. Como a ciência, nessa perspectiva, só pode lidar com o que é comprovável, objetificável, e como a religião, assim entendida, não é passível de comprovação, o ER como ensino de religião não deve ter lugar em meio às demais disciplinas das Humanidades. $O$ estudo de religião não pertence, por isso, ao ambiente escolar. Nem possui cientificidade suficiente para tanto. Além do que, nessa perspectiva, o ER será fatalmente proselitista. ${ }^{5}$

Questões análogas a esta são ainda constantemente levantadas. Por exemplo, o argumento de que o Brasil é um país laico e, portanto, a escola pública não deveria ter ER. Este e outros argumentos correlatos implicam na cisão entre a religião e certo entendimento da sociedade moderna, entre a crença na relação com seres sobrenaturais e a situação do homem moderno racional, que não pode conviver com o que entende como formas irracionais religiosas. Criando-se, nesse sentido, uma área específica para o ER na BNCC, blinda-se as Humanidades em relação às insanidades pré-modernas da religião, deixando o ER com suas próprias idiossincrasias. A questão está longe de se resolver.

Mas tudo isso depende, é claro, primeiramente do conceito de religião com o qual se opera. Superar essa divisão artificial entre razão e religião é algo que urge no tocante ao debate sobre o ER. De qualquer forma, o fato de o ER estar presente na BNCC nos abre um precedente interessantíssimo para a reflexão e a prática no campo da interface religião-educação.

\section{Horizontes desde a Ciência da Religião}

\subsection{O Ensino Religioso como disciplina das Humanidades}

Iniciemos pela última questão. É possível pensar a religião academicamente fora do enquadramento da relação com seres sobrenaturais, ou estes são de fato pressupostos do ER? Há, na verdade, uma longa tradição de estudo acadêmico da religião fora dessa perspectiva. Podemos pensar em pelo menos dois modelos principais.

É possível, ainda, também por outro lado, pensar sobre a adequação dos termos "confessional/nãoconfessional" para o trato do problema em questão. Ora, todo processo pedagógico tem um fundamento, uma proposta, coisas nas quais se acredita ao educar. Nesse sentido, o ensino não-confessional também tem suas crenças e fundamentos; também tem sua confissão. Por isso, talvez o binômio "catequético/nãocatequético" coloque melhor o problema implicado no debate. A questão, nesse sentido, não é ser "nãoconfessional" (uma vez que sempre se parte de um fundamento filosófico ou religioso) mas sim ser "nãocatequético", termo que favorece o entendimento de um ER plural e inclusivo.

5 Ver a crítica da epistemologia cientificista da religião em Alves (1984). 
a) Um é o modelo funcional, a partir do qual entende-se que, uma vez que ideias como as de Deus e da imortalidade da alma estão além do conhecimento que pode ser alcançado pela razão finita, a religião precisa ser compreendida apenas nos limites dessa mesma razão, devendo ser percebida em seus efeitos, implicações e consequências.

Tal é a perspectiva hegemônica, por exemplo, nas Ciências Sociais, que se concentram nas funções que a religião exerce na sociedade e na cultura. Trata-se de um ponto de vista útil e do qual aprende-se muito sobre os efeitos da religião enquanto fenômeno humano. Tal perspectiva, todavia, corre sempre o risco de sublinhar mais tais efeitos que a própria religião, enquanto horizonte de sentido e de constituição de visões de mundo. $\bigcirc$ marxismo, por exemplo, tende a sublinhar mais os efeitos da religião em termos econômicos e de alienação, o que não esgota, em princípio, o que a religião representa ou seu significado potencial em termos humanos e existenciais. ${ }^{6}$ A questão do ensino de religião como ensino de valores, acima elencada, enquadra-se nessa mesma perspectiva, à medida que se compreende a dimensão ética como uma das funções da religião. Essa seria uma perspectiva amparada, em termos de teoria social, por exemplo, em Durkheim (1996, p. 457ss) - a religião como fator de solidariedade e coesão social. Outros tantos autores amplamente utilizados poderiam ser listados nesse horizonte: Weber, Bourdieu, Geertz, etc.7

b) Outra possibilidade é assumir que fundamentalmente a religião de fato não pertence às coisas objetificáveis, comprováveis. Sua constituição tem a ver com o sentido da vida, com o coração humano. Trata-se do modelo substantivo.

Aqui a questão central também não é sobre seres sobrenaturais, quaisquer que sejam os nomes a eles atribuídos, mas toca à existência humana e ao sentido do ser. Entendemos que esse é o modelo que mais favorece o ER e a Ciência da Religião. Rubem Alves (1981) fala que a religião é a presença de uma ausência. Que os símbolos religiosos representam os sonhos melhores e mais significativos da aventura humana. Aquilo que desejamos mais profundamente. Assim, antes de adaptar as pessoas ao que existe, a religião as incita a sonhar novos mundos, novas formas de convivência. A religião, na verdade, constitui um modo de protesto que diz que o mundo não deveria ser como é, e que o que ele deveria ser ainda não se concretizou. Trata-se de um horizonte, uma utopia, um não-lugar. Essa inadaptação à vida como é dada, essa incompletude, que é algo constitutivo da humanidade, é ao mesmo tempo uma realidade acerca da qual não conseguimos falar claramente, como pretende a linguagem científica, é, antes, algo que habita as profundezas da alma humana. Tal é a origem e o sentido da vida religiosa. $\bigcirc$ que vem depois disso são "as religiões", que nessa perspectiva podem ser pensadas como a ponta de um iceberg. A religião assim compreendida é uma força, uma vontade, uma potência, algo que dinamiza a vida e que tem, é claro, efeitos diversos, sociais, culturais, pessoais, etc. Ou seja, a religião é um ímpeto de sentido fundamental que move as demais esferas da vida humana, constitui o coração e o centro pulsante da vida e da cultura, aquilo que desejamos mais ardentemente, que anelamos com maior esperança, que sonhamos de modo mais criativo. Trata-se daquilo que Paul Tillich (1996, p. 11) chamava de "preocupação incondicional ou última" e de "paixão infinita". As instituições sociais, as práticas culturais, as linguagens mais diversas, as próprias religiões e suas teologias são fruto desta força primeira, que demonstra a capacidade de autotranscendência humana. "O fato de o homem ter uma preocupação última revela algo de sua natureza, isto é, que ele tem a capacidade de transcender o fluxo contínuo de experiências finitas e passageiras",

6 Para essa questão, ver, p. ex., Alves (1984).

7 Ainda que não toque diretamente na questão que levantamos, uma boa introdução à sociologia da religião está em Teixeira (2003). 
diz Tillich (1996, p. 11). Para o teólogo, "o homem, num ato direto, pessoal e central é capaz de captar o sentido do que é último, incondicional, absoluto e infinito" (TILLICH, 1996, p. 11).

Falar sobre religião pressupondo esse entendimento pode ajudar a vislumbrar uma forma de ER que tenha pertença ao conjunto das Humanidades (Linguagens e Ciências Humanas na BNCC). Religião, nessa perspectiva, tem a ver com a vida, com as pessoas. A questão é como lidar com isso academicamente, uma vez que as demais disciplinas raramente percebem a religião de forma substantiva, limitando-se, quando muito, à sua compreensão funcionalista.

Um dos modos de colocar tal questão, que pode ser atualmente eficaz, é perspectivar o ER em relação às demais disciplinas conforme a redação da BNCC. De fato, o ER como ensino de religião, assim compreendido, estaria em sintonia com as principais propostas e horizontes constantes na BNCC. Vejamos, por exemplo, algumas das competências gerais esperadas pela Base:

1. Valorizar e utilizar os conhecimentos historicamente construídos sobre o mundo físico, social, cultural e digital para entender e explicar a realidade, continuar aprendendo e colaborar para a construção de uma sociedade justa, democrática e inclusiva. [...]

3. Valorizar e fruir as diversas manifestações artísticas e culturais, das locais às mundiais [...]

9. Exercitar a empatia, o diálogo, a resolução de conflitos e a cooperação, fazendo-se respeitar e promovendo o respeito ao outro e aos direitos humanos, com acolhimento e valorização da diversidade de indivíduos e de grupos sociais, seus saberes, identidades, culturas e potencialidades, sem preconceitos de qualquer natureza (BRASIL, 2018, p. 9-10).

A compreensão substantiva da religião proporciona uma horizontalização do fenômeno, no sentido de percebê-lo em sua abrangência humana, como produção de sentido fundamental à existência, e permite compreender o universo das religiões em sua diversidade, de forma nãohierárquica e não-proselitista. Vale, porém, dizer que, nessa perspectiva, as religiões, como qualquer fenômeno histórico humano, são ambíguas, ao mesmo tempo boas e más, com suas luzes e suas sombras.

Tillich dizia que a história das religiões deveria ser a história do que toca e move as pessoas de modo incondicional (TILLICH, 1985). À medida em que nos aproximamos da religião como a dinâmica pulsante da vida, a percebemos como o fundamento da própria existência, da vida social e cultural. A sabedoria religiosa das diversas tradições compõe por isso um leque de conhecimentos e de sabedorias que desvendam o mundo vivido pela humanidade em sua rica diversidade, abrindo horizontes de entendimento da vida. $\bigcirc$ conhecimento dos símbolos, ritos, mitos, doutrinas, experiências e formas sociais das religiões além de compor o leque de saberes em relação aos quais a escola tem uma vocação mediadora, constitui, assim também, uma disposição para o diálogo, o respeito, a empatia e a solução de conflitos. Estes são horizontes que devem compor o ER, e que se sintonizam perfeitamente com os fundamentos pedagógicos presentes na BNCC.

De outra forma, a linguagem religiosa, deveria constar como componente que pertence às demais linguagens elencadas pela Base, o que ainda não ocorreu. ${ }^{8} \mathrm{~A}$ linguagem religiosa, como a compreendemos, pode de fato ser percebida como fundante das demais linguagens, mesmo

8 Cf. o texto da BNCC: "4. Utilizar diferentes linguagens - verbal (oral ou visual-motora, como Libras, e escrita), corporal, visual, sonora e digital -, bem como conhecimentos das linguagens artística, matemática e científica, para se expressar e partilhar informações, experiências, ideias e sentimentos em diferentes contextos e produzir sentidos que levem ao entendimento mútuo" (BRASIL, 2018, p. 7). 
anterior a elas, uma vez que as informa e as preenche com um sentido de profundidade. Ela, seja como for, é constitutiva fundamental do modo como as pessoas e grupos expressam suas experiências e constroem seu entendimento mútuo. Nesse sentido, o ER se identifica e sintoniza também com as competências esperadas na área de Linguagens:

1. Compreender as linguagens como construção humana, histórica, social e cultural, de natureza dinâmica, reconhecendo-as e valorizando-as como formas de significação da realidade e expressão de subjetividades e identidades sociais e culturais.

2. Conhecer e explorar diversas práticas de linguagem (artísticas, corporais e linguísticas] [também as religiosas! Nota do autor] em diferentes campos da atividade humana para continuar aprendendo, ampliar suas possibilidades de participação na vida social e colaborar para a construção de uma sociedade mais justa, democrática e inclusiva. (BRASIL, 2018, p. 65)

Afirma Tillich (1996, p. 30) que "o que toca o homem incondicionalmente precisa ser expresso por meio de símbolos, porque apenas a linguagem simbólica consegue expressar o incondicional". 9 Os símbolos religiosos levam a níveis da realidade que, não fossem eles, seriam inacessíveis. Por isso, o contato com os símbolos religiosos, os objetos sacralizados pela humanidade na história, os ritos e mitos envolvidos, as ideias e teologias empregadas para aprofundar seus sentidos, compõe uma gama poderosa de potenciais experiências profundamente humanizadoras, das quais se vale o ER.

Em relação à área de Ciências Humanas, a similaridade de interesses do ER é, por sua vez, assim também tão clara:

1. Compreender a si e ao outro como identidades diferentes, de forma a exercitar o respeito à diferença em uma sociedade plural e promover os direitos humanos.

2. Analisar o mundo social, cultural e digital e o meio técnico-científicoinformacional com base nos conhecimentos das Ciências Humanas, considerando suas variações de significado no tempo e no espaço, para intervir em situações do cotidiano e se posicionar diante de problemas do mundo contemporâneo.

4. Interpretar e expressar sentimentos, crenças e dúvidas com relação a si mesmo, aos outros e às diferentes culturas, com base nos instrumentos de investigação das Ciências Humanas, promovendo o acolhimento e a valorização da diversidade de indivíduos e de grupos sociais, seus saberes, identidades, culturas e potencialidades, sem preconceitos de qualquer natureza (BRASIL, 2018, p. 357).

Uma das críticas que se faz à compreensão substantiva da religião é a de essencializar e reificar a experiência humana, como que "achatando" sua rica diversidade. Nessa perspectiva, não se poderia falar em "religião" mas sempre em "religiões", não sendo possível uma definição abrangente que contemple toda a realidade humana. Tal crítica pode ser rebatida facilmente. Em primeiro lugar, a despeito da real diversidade das religiões e da incompletude e parcialidade dos conceitos atribuídos à religião, a cada vez que se pensa, se estuda e se escreve sobre religião nas

9 Vale sublinhar que, para Tillich, o incondicional não é um ser, cuja existência precise ser provada ou discutida, mas uma qualidade da experiência humana, sua dimensão sagrada, de validade última. 
Humanidades, parte-se de um entendimento prévio do termo. Ou seja, estamos condicionados à produção de um conceito de religião, sob pena de não conseguirmos desenvolver nosso ofício. Isso, na verdade, é sempre o que acontece com conceitos abstratos tais como sociedade, cultura, política, etc. A atividade teórica, labor das Humanidades, vive de abstrações. Basta que pensemos nelas sempre como incompletas, datadas e perspectivadas ou enviesadas. Em segundo lugar, uma visão substantiva consistente acerca da religião, a perceberá sempre em duas dimensões, a saber, uma essencial, ontológica, "a religião", e outra relativa, histórica, "as religiões". Nesse sentido, não existe a religião sem as religiões. De outra forma, o entendimento da diversidade das religiões torna-se plenamente pedagógico apenas ao passo em que se permite também entrever sua unicidade, ou seja, aquilo que torna abrangentemente humano o fenômeno religioso. De fato, o mesmo pressuposto ideal que permite falar em humanidade, permite também falar em religião. A religião, essencial, e as religiões, históricas, são as duas faces da moeda do $E R$, que the conferem uma compreensão dinâmica da cultura e da sociedade, potencializando uma formação simultaneamente crítica e acolhedora. Ademais, perceber o outro não apenas como diferente, mas também como humano, ou seja, semelhante, é um elemento crucial no processo pedagógico que aqui nos interessa. Trata-se da dialética entre identidade e diferença.

A pertença do ER à educação básica e ao conjunto das Humanidades está, por fim, atestada também claramente nos objetivos do próprio ER, conforme o texto da Base:

\begin{abstract}
O Ensino Religioso busca construir, por meio do estudo dos conhecimentos religiosos e das filosofias de vida, atitudes de reconhecimento e respeito às alteridades. Trata-se de um espaço de aprendizagens, experiências pedagógicas, intercâmbios e diálogos permanentes, que visam o acolhimento das identidades culturais, religiosas ou não, na perspectiva da interculturalidade, direitos humanos e cultura da paz. Tais finalidades se articulam aos elementos da formação integral dos estudantes, na medida em que fomentam a aprendizagem da convivência democrática e cidadã, princípio básico à vida em sociedade (BRASIL, 2018, p. 437).
\end{abstract}

A religião, assim percebida como o centro pulsante de significação da vida e sua expressão em formas culturais (ritos, mitos, doutrinas, moral, etc.), permite, portanto, alocar seu estudo e seu ensino acadêmico no conjunto das Humanidades. O ER e a Ciência da Religião possuem, nesse sentido, um parentesco genético com as demais disciplinas que tangenciam, ainda que indiretamente, o estudo da religião, delas se beneficiando e complementando suas variadas perspectivas.

Tem se tornado crescente consenso, nesse entendimento, que a Ciência da Religião é a casa acadêmica do ER, assim como o é a História para o Ensino de História, por exemplo. A CR deve, por isso, constituir uma espécie de usina na qual se forja e se testa o que é traduzido pedagogicamente no ER (SOARES, 2009; TEIXEIRA, 2011; JUNQUEIRA, 2013; GROSS, 2014; BAPTISTA, 2015; RODRIGUES, 2015).

\title{
2.2. O específico do ER é o e ensino de religião no contexto da Ciência da Religião
}

O que, afinal, o ER oferece que Ihe é próprio, à diferença das demais disciplinas? A resposta é: um amplo conhecimento sobre a religião como fenômeno humano de sentido e sobre as mais diversas religiões enquanto resultados históricos dessa força de vida religiosa. A linguagem simbólico-religiosa estrutura um lugar de onde se vê o mundo e se imagina como ele é e como ele deveria ser. A visão de mundo coloca ordem no caos da existência e cria um lugar habitável para se viver, mas também capacita à renovação da vida e à transformação social. 
Ao definir o objeto da CR ao redor do estudo das visões de mundo, Ninian Smart escreve (1995, p. 1):

Os seres humanos fazem a maior parte das coisas ou porque recebem algo em troca, ou porque têm medo de fazer de outro modo, ou porque acreditam. $\bigcirc$ moderno estudo da religião diz respeito ao último destes motivos - os sistemas de crença que, através de símbolos e ações, mobilizam os sentimentos e vontades dos seres humanos. (...) o moderno estudo da religião ajuda a iluminar visões de mundo, tanto tradicionais quanto seculares, que constituem um motor de continuidade e mudança social e moral; e, portanto, explora crenças e sentimentos, e tenta compreender o que existe na mente das pessoas.

É preciso, nesse sentido, debruçar-se sobre a religião como um fenômeno encompassante, total, holístico, porque consiste em um fundamento das coisas que se faz, se pensa, se acredita, se sonha. Conforme Smart (1995, p. 2), trata-se de fazer referência "ao que as pessoas sentem, às ideias que elas têm, às estruturas de crença de sua sociedade - em suma, à consciência humana". Ao estudo desse objeto, composto por visões de mundo tanto religiosas quanto seculares, Smart dá o nome de "análise de visão de mundo", que "busca descrever a história e a natureza das crenças e símbolos que formam a parte profunda da estrutura da consciência e da sociedade humana" (SMART, 1995, p. 2). Os símbolos e as crenças religiosas são, nessa perspectiva, a presença da ausência, no entender de Rubem Alves, o resultado histórico-cultural da força de vida que move a humanidade, sua preocupação última, nas palavras de Tillich.

À Ciência da Religião, chamada por Smart de "moderno estudo da religião", cabe, portanto, um estudo não somente transcultural, mas também transdisciplinar da religião (SMART, 1995, p. 4-5). Costuma-se dizer que a disciplina é polimetódica, o que significa assumir que deve debruçar-se sobre esse multifacetado fenômeno com o auxílio de aportes teóricometodológicos diversos, dependendo do problema definido na pesquisa. Em seu empreendimento, portanto, a CR é constitutivamente dialógica em relação às demais disciplinas das Humanidades.

O que devem então saber cientistas da religião e professores de ER? Ora, devem saber sobre as religiões. Possuir uma visão ampla e sólida acerca da religião enquanto fenômeno humano. Licenciados em CR, por sua vez, ou professores de ER que bebem da CR devem estar capacitados a levar para a sala de aula essa ampla perspectiva sobre o universo das religiões no Brasil e no mundo, suas principais tradições, ideias, textos, mitos, ritos, símbolos - os aspectos que compõem a estrutura profunda da consciência e da sociedade humana. Portanto, também as repercussões das religiões em termos de sociedade e cultura, política, arte, economia, etc. Pessoas preparadas para auxiliar a comunidade escolar a sair do senso comum acerca da religião, a abrir novos horizontes de entendimento sobre o mundo das religiões, a sabedoria religiosa acumulada pela humanidade, e assim também novas formas de entendimento da vida.

Veja-se que isso tudo é muito diferente de catequese. A origem etimológica da palavra "catequese" é grega e quer dizer "instruir, ensinar oralmente", referindo-se tradicionalmente aos elementos do cristianismo. Bem, não é disso que se trata, obviamente, seja qual for o lócus interno ao cristianismo em que nos posicionamos, ou de qualquer outra religião. A posição desejável de professores de ER não é catequética, mas humanista, no sentido de mediar, através dos símbolos e tradições religiosas, o contato dos alunos com a sabedoria religiosa acumulada pela humanidade, também sua percepção da religião enquanto fenômeno humano que tem implicações para a vida, apontando suas luzes e suas sombras. Veja-se que o processo aqui não é informativo, ou conteudista, mas interpretativo, hermenêutico, dialógico. A intenção não é a de criar bons fieis pela instrução, mas de estimular o crescimento de humanos pensantes e sensíveis em relação ao seu lugar no mundo. É o que acontece quando conhecemos o universo 
das religiões, suas diversas manifestações histórico-culturais e seu lugar no coração das pessoas. O ER, assim elaborado, pode promover um processo de humanização e colaborar com as demais disciplinas para dar lugar ao florescimento de pessoas mais inteligentes, mais afetivas, mais críticas, mais criativas. A primeira competência almejada para o ER na Base está assim formulada: "Compreender a si e ao outro como identidades diferentes, de forma a exercitar o respeito à diferença em uma sociedade plural e promover os direitos humanos" (BRASIL, 2018, p. 353). Agregue-se a isso, dialeticamente, a ideia correlata de unicidade e pluralidade, ou, em termos fenomenológicos, essência e manifestação, e teremos um instrumento poderoso de educação.

Por fim, deve-se mencionar ainda a constituição recente da subárea de Ciência da Religião Aplicada, como componente da área de Ciências da Religião, dentre as demais subáreas de sua árvore do conhecimento: Epistemologia das Ciências da Religião; Ciências Empíricas da Religião; e Ciências da Linguagem Religiosa.10 Segundo Afonso Soares (2013, p. 573) trata-se de "pensar a Ciência da Religião a partir dos frutos sociais que dela se esperam". O ER compõe um dos interesses mais claros da Ciência da Religião Aplicada.

Sérgio Junqueira (2013) argumenta, nesse sentido, que o ER é a transposição didática da Ciência da Religião, a aplicação dos resultados dos estudos feitos no âmbito da CR ao cotidiano da sala de aula. A CR deve, portanto, "orientar o conteúdo e a forma do processo de educação chamado de ensino religioso" (SOARES, 2013). Daí o traço aplicado do Ensino Religioso em relação à Ciência da Religião. Enquanto Ciência da Religião Aplicada, o ER "incentiva e promove uma ação orientada, crítica, comunicativa, político social da Ciência da Religião" (TWORUSCHKA, 2013, p. 578), implicando não apenas em descrever e analisar os atos religiosos, mas também em lidar com processos de mediação, a fim de transformar os horizontes de compreensão social e de facilitar a resolução de conflitos. A Ciência da Religião Aplicada e o ER possuem, nessa perspectiva, horizontes de atuação "pacificadores, humanizadores e conciliadores" (TWORUSCHKA, 2013, p. 578).

Muito ainda há de se pensar acerca do Ensino Religioso como ensino de religião na escola, bem como acerca de sua intrínseca relação com a Ciência da Religião. Estas são apenas algumas provocações e considerações a que pude chegar e a dar forma neste escrito.

\section{Referências}

ALVES, Rubem. O que é religião. São Paulo: Brasiliense, 1981. . O suspiro dos oprimidos. São Paulo: Paulinas, 1984.

BAPTISTA, Paulo Agostinho Nogueira. Ciências da Religião e Ensino Religioso: o desafio histórico da formação docente de uma área de conhecimento. REVER, Ano 15, $\mathrm{N}^{\circ}$ 02, Jul/Dez 2015, p. 107-125.

BRASIL. Ministério da Educação. Base Nacional Comum Curricular (BNCC). Brasília, 2018. Disponível em: $<$ http:/ / basenacionalcomum.mec.gov.br/images/BNCC_EI_EF_110518_versaofinal_site.pdf> Acesso em 05/12/2019.

10 Note-se que, diferentemente da BNCC, no âmbito da CAPES, em sua árvore do conhecimento, a área de Ciências da Religião e Teologia encontra-se sob a grande área de Ciências Humanas, estando aí, portanto, também alocado o Ensino Religioso como espaço de atuação e reflexão da Ciência da Religião Aplicada. Cf. $<$ https:// capes.gov.br/images/documentos/Criterios_apcn_2016/Criterios_APCN_Teologia.pdf >; acesso em 04/05/2018. 
DIAS, Zwinglio Mota. Fundamentalismo: o delírio dos amedrontados (anotações sócio-teológicas sobre uma atitude religiosa). Tempo e presença digital, ano 3, n. 13, dezembro de 2008. Disponível em: <http:/ / www.koinonia.org.br/tpdigital/ detalhes.asp?cod_artigo=254\&cod_boletim=14\&tipo= Artigo > Acesso em 07/05/2018.

DREHER, Martin N. Fundamentalismo. São Leopoldo: Sinodal, 2006.

DURKHEIM, Émile. As formas elementares da vida religiosa, o sistema totêmico na Austrália. São Paulo: Martins Fontes, 1996.

GIUMBELLI, Emerson. O "baixo espiritismo" e a história dos cultos mediúnicos. Horizontes Antropológicos, Porto Alegre, v. 9, n. 19, p. 247-281, Julho de 2003 . Disponível em: <http:/ / www.scielo.br/ scielo.php?script=sci_arttext\&pid=S0104718320030001000118Ing=en\&nrm=iso >. Acesso em 07/05/2018.

GROSS, Eduardo. Conhecimento sobre religião, Ciência da Religião e Ensino Religioso. Numen. revista de estudos e pesquisa da religião, Juiz de Fora, v. 17, n. 1, 2014, p. 119-138.

MARTY, Martin E. O que é fundamentalismo: perspectivas teológicas. Concilium, Petrópolis, v. 241, n. 3, p. 13-26, 1992.

RODRIGUES, Elisa. Ciência da Religião e Ensino Religioso, efeitos de definições e indefinições na construção dos campos. REVER, Ano 15, Nº 02, Jul/Dez 2015.

SMART, Ninian. Worldviews, crosscultural explorations of human beliefs. 2. ed. New Jersey: Prentice Hall, 1995.

SOARES, Afonso Maria Ligorio. Ciência da Religião, Ensino Religioso e formação docente. REVER, setembro/2009, p. 1-18.

Introdução à Parte V. In: PASSOS, João Décio; USARSKI, Frank (orgs.). Compêndio de Ciência da Religião. São Paulo: Paulinas; Paulus, 2013.

SILVA, Vagner Gonçalves da (org.). Intolerância religiosa. impactos do neopentecostalismo no campo religioso afro-brasileiro. São Paulo: Editora da Universidade de São Paulo, 2007.

TEIXEIRA, Faustino. O "ensino do religioso" e as Ciências da Religião. Horizonte, Belo Horizonte, v. 9, n. 23, out./dez., 2011, p. 839-861.

(org.). Sociologia da religião, enfoques teóricos. Petrópolis: Vozes, 2003.

TILLICH, Paul. Dinâmica da fé. $5^{a}$ ed. São Leopoldo: Sinodal, 1996.

VAINFAS, Ronaldo; SOUZA, Juliana Beatriz de. Brasil de Todos os Santos. Rio de Janeiro: Jorge Zahar Editor, 2000. 